\title{
Hereditary spastic paraplegia: a clinical and epidemiological study of a Brazilian pediatric population
}

\author{
Paraplegia espástica hereditária: estudo clínico e epidemiológico em uma população \\ pediátrica brasileira
}

Roberta Paiva Magalhães Ortega', Sérgio Rosemberg',2

\begin{abstract}
Aims: To investigate hereditary spastic paraplegia (HSP) in a pediatric Brazilian sample. Methods: Epidemiological, clinical, radiological and laboratory data were analyzed in 35 patients. Results: Simple HSP (HSP-S) was detected in 12 patients, and complicated HSP (HSP-C) was detected in 23 patients. The mean age of onset of symptoms was 2.9 years in HSP-S and 1.6 years in HSP-C ( $p=0.023)$. The disease was more severe in HSP-C. There were no differences in sex, ethnic background, or family history between groups. Intellectual disability was the most frequent finding associated with HSP-C. Peripheral axonal neuropathy was found in three patients. In the HSP-C group, MRI was abnormal in 13 patients. The MRI abnormalities included nonspecific white matter lesions, cerebellar atrophy, thinning of the corpus callosum and the "ear of the lynx sign". Conclusions: In children with spastic paraplegia, HSP must be considered whenever similar pathologies, mainly diplegic cerebral palsy, are ruled out.
\end{abstract}

Keywords: Spastic paraplegia; hereditary; cerebral palsy; heredodegenerative disorders, nervous system.

\section{RESUMO}

Objetivo: Investigar paraplegia espástica hereditária (PEH) em uma amostra brasileira de pacientes pediátricos. Métodos: Foram colhidos dados clínicos, epidemiológicos, radiológicos e laboratoriais de 35 pacientes. Resultados: Doze pacientes foram classificados como PEH simples (PEH-S), e 23 como PEH complicada (PEH-C). A média de idade de início dos sintomas foi de 2,9 anos na PEH-S e 1,6 anos na PEH-C ( $p=0,023)$. A doença foi mais grave na PEH-C. Não houve diferença de sexo, etnia e histórico familial entre os dois grupos. Deficiência intelectual foi a associação clínica mais frequente na PEH-C. Neuropatia periférica axonal foi encontrada em três pacientes. A RM foi normal em 13 casos de PEH-C. Anormalidades de RM incluiram alterações inespecíficas da substância branca, atrofia de cerebelo, afilamento de corpo caloso e o "sinal da orelha de lince". Conclusões: PEH deve ser considerada em crianças com paraparesia espástica sempre que descartadas condições patológicas similares, principalmente paralisia cerebral.

Palavras-chave: Paraplegia espástica hereditária; paralisia cerebral; transtornos heredodegenerativos do sistema nervoso.

Hereditary spastic paraplegia (HSP) is a group of neurodegenerative disorders with great genetic and phenotypic heterogeneity. Clinically, HSP is predominantly characterized by progressive spasticity of the lower limbs, with no other verifiable causes ${ }^{1}$. Its prevalence is estimated to be between 1.3 and 9.6 per 100,000 individuals ${ }^{2}$.

HSP can be classified as simple (HSP-S) or complicated (HSP-C). In the simple or pure form, the predominant clinical condition is a progressive spastic paraplegia with hyperreflexia, Babinski sign, ankle clonus and increased tone in the lower limbs, which may also be associated with mild sensory deficits in the lower limbs and bladder dysfunction.

In the complicated form, spastic paraplegia is associated with other neurological or extra-neurological signs such as mental deficiency, ataxia, peripheral neuropathy, epileptic seizures, deafness, optic atrophy, ichthyosis, among others ${ }^{3}$.

Differential diagnosis includes structural abnormalities such as malformations, tumors of the brain or spinal cord, cerebral lesions due to pre- or perinatal anoxia,

${ }^{1}$ Irmandade da Santa Casa de Misericórdia de São Paulo, São Paulo SP, Brasil;

${ }^{2}$ Faculdade de Ciências Médicas da Santa Casa de São Paulo, São Paulo SP, Brasil.

Roberta Paiva Magalhães Ortega (iD) https://orcid.org/0000-0003-4323-7916

The study was carried out at the Irmandade da Santa Casa de Misericórdia de São Paulo, São Paulo/SP - Brasil.

Correspondence: Roberta Paiva Magalhães Ortega; Rua Cesário Motta Júnior, 112; 01221020 São Paulo SP, Brasil; E-mail: romagalhaes@hotmail.com

Conflict of interest: There is no conflict of interest to declare.

Received 05 April 2018; Received in final form 27 August 2018; Accepted 15 October 2018. 
inflammatory/infectious conditions such as AIDS, syphilis, human T-cell leukemia virus type 1 (tropical spastic paraplegia), metabolic diseases such as arginase deficiency, homocysteinemia, vitamin B12 deficiency, vitamin E deficiency, copper deficiency, serine deficiency, leukodystrophies (Krabbe's disease, adrenoleukodystrophy, metachromatic leukodystrophy), among others ${ }^{4,5,6}$.

The brain scan is often normal, but possible anomalies include thinning of the corpus callosum, cerebellar atrophy, and nonspecific changes in the white matter ${ }^{3}$.

Over 70 distinct loci and over 50 genes have been identified in the genesis of the disease ${ }^{7}$. Thus, each type of HSP is named as SPG (spastic paraplegia gene) followed by the number representing the chronological order of identification of the genetic locus. Transmission may be recessive, dominant, X-linked or mitochondrial ${ }^{8,9,10}$.

There is a consensus among authors that the transmission of HSP-S is usually autosomal dominant, whereas HSP-C is autosomal recessive ${ }^{11}$.

In individuals where the symptoms begin in childhood, disease progression tends to be very slow, resembling nonprogressive chronic encephalopathy (cerebral palsy), which is the main differential diagnosis in children with spastic paraplegia ${ }^{12}$.

The American Academy of Neurology recommends that metabolic and genetic testing should be considered in children with spastic paraplegia if their clinical record or neuroimaging findings are insufficient for establishing a specific diagnosis, or if there are other additional atypical features in their history or clinical examination ${ }^{13}$.

Therefore, the diagnosis of HSP should be considered in those children with spastic paraplegia whose pathogenic mechanisms remain obscure after laboratory investigation.

Studies involving HSP in children are scarce in the international literature. A recent study on historical aspects of these diseases points out the absence of such studies in Brazil ${ }^{14}$. Our goals were to highlight the clinical and epidemiological aspects of pediatric HSP in a Brazilian sample.

\section{METHODS}

Clinical, observational and analytical studies were performed in patients with a clinical diagnosis of HSP, followed up between 2003 and 2016 at the Neuropediatric Division of Santa Casa de São Paulo, Brazil.

The analyzed data were: sex, skin color, age at onset of symptoms, age at first appointment, time elapsed between onset of symptoms and final diagnosis, and family history. Patients were clinically examined and classified as having pure or complicated spastic paraplegia, based on established diagnostic criteria ${ }^{1,3}$. Patients were characterized as having a progressive condition if, during their follow-up, worsening of their motor condition was detected through the neurological examination including the Medical Research Council scale. The date of onset of symptoms was provided by the mother or guardian. Intellectual disability (intellectual development disorder) was diagnosed in children older than five years at the time of data collection according to DSM-5 criteria $^{15}$. Magnetic resonance imaging (MRI) of the brain and spinal cord, electromyography, cerebrospinal fluid, fundoscopy, auditory assessment with audiometry or auditory evoked potentials (depending on the patient's collaboration), human T-cell leukemia virus type 1, HIV and Venereal Disease Research Laboratory serologies, serum levels of vitamin B12, vitamin E, copper, ceruloplasmin, ammonia, homocysteine and arginine were performed. Depending on the clinical presentation, hexosaminidase A, galactocerebrosidase, serum immunoglobulins, alpha-fetoprotein, electrocardiogram or peripheral blood acanthocyte analysis were also performed. After this comprehensive clinical and laboratory screening, the patients who did not fit the diagnosis of HSP were excluded from the sample. The examinations are listed in Figure 1.

\section{Statistical analysis}

The SPSS software, version 13.0, was used for conducting the statistical analysis. In the descriptive analysis, absolute and relative frequencies were used for qualitative variables, whereas summary measures were used for quantitative variables. Normality of the data was tested with the Shapiro-Wilk test and nonparametric tests were used for non-normally distributed data. For the statistical inference, the following tests were conducted: Fisher's exact test (small sample size) or chi-squared (qualitative X qualitative variables), in addition to the nonparametric Student's $t$ and Mann-Whitney tests (quantitative variables $\mathrm{X}$ simple or complicated group). Statistical significance was defined as $\mathrm{p}<0.05$. The statistical study was carried out by the Department of Statistics of the graduate program of the School of Medicine at Santa Casa de São Paulo.

\section{Research ethics committee}

Guardians, parents and patients agreeing to participate in the study signed a voluntary and informed consent form. The study was approved by the Research Ethics Committee of Irmandade da Santa Casa de Misericórdia de São Paulo, as well as by the Research Ethics Committee of UNICAMP University of Campinas, Brazil.

\section{RESULTS}

\section{Epidemiological and clinical data}

Thirty-five patients were studied, of whom 12 (34.2\%) had HSP-S and 23 (65.8\%) had HSP-C. 


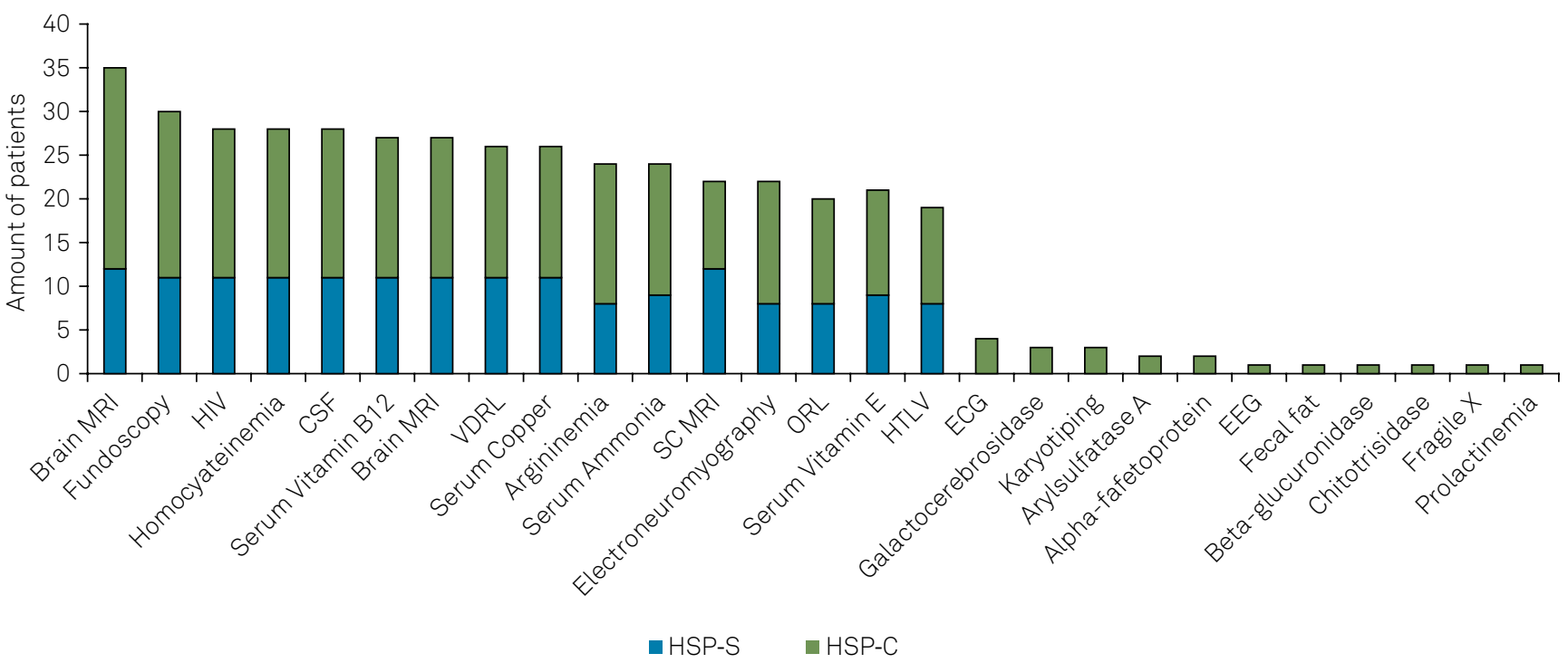

Brain MRI: Brain magnetic resonance imaging; HIV: human immunodeficiency virus serology; CSF: cerebrospinal fluid; VDRL: Venereal Disease Research Laboratory non-treponemal test for syphilis; SC MRI: Spinal cord magnetic resonance imaging; ORL: evaluation conducted by an otorhinolaryngologist; HTLV: human T-cell lymphotropic virus type 1 serology; ECG: electrocardiogram; EEG: electroencephalogram.

Figure 1. Clinical, radiology and laboratory screening.

\section{Simple hereditary spastic paraplegia - HSP-S}

Of the 12 patients, seven $(58.3 \%)$ were male and five $(41.7 \%)$ were female. Six patients $(50 \%)$ were white, four (33.3\%) were brown, one $(8.3 \%)$ was yellow and one patient $(8.3 \%)$ was black.

Regarding family history, four (33.3\%) had at least one affected relative, such as parent or grandparent and two (16.6\%) had a history of parental consanguinity.

The mean age at onset of symptoms was 2.9 years (ranging from 0.8 to 10.8 years), with a median of 1.5 years. The mean age at the time of the first appointment in our outpatient service was 5.1 years (minimum 1.5 and maximum 11.9 years of age), with a median of 4.9 years. The mean time between onset of symptoms and diagnosis was three years, with a median of two years (the minimum age was 0 and the maximum age was 8.2 years).

Seven $(58.3 \%)$ reported progression of their symptoms during follow-up, while five $(41.7 \%)$ did not report any motor worsening.

Eleven patients $(91.6 \%)$ had independent gait at the last neurological evaluation, whereas one patient (8.3\%) needed support to ambulate. This patient, first seen at age 11, is now 25 years old and has required a wheelchair since age 21 . The clinical and epidemiological data are listed in Table 1.

\section{Complicated hereditary spastic paraplegia - HSP-C}

Of the 23 patients, 11 (47.8\%) were male and $12(52.1 \%)$ were female. Eleven patients (47.8\%) were brown, $10(43.5 \%)$ were white, and two patients $(8.6 \%)$ were black.

Regarding their family history, nine patients (39.1\%) had at least one affected relative (seven had affected siblings and two had an affected uncle and cousin). In this sample, there were two pairs of siblings. Four patients (17.4\%) had a history of parental consanguinity.

The mean age at onset of symptoms was 1.6 years (ranging from 0 to 11 years), with a median of one year. The mean age at the time of the first appointment was 4.3 years (minimum 0.5 and maximum 15.2 years of age), with a median of 2.2 years. The mean time between onset of symptoms and diagnosis was 6.4 years, with a median of 5.5 years (ranging between 0.8 and 14.4 years of age).

Seventeen patients $(73.9 \%)$ reported progression of their clinical condition, while six patients (26.0\%) did not report any worsening. Eight patients $(34.8 \%)$ had independent gait at the last neurological evaluation, whereas seven patients (30.4\%) needed support to ambulate, and eight (34.8\%) were restricted to a wheelchair, five of whom have never walked. One of these patients has a sister diagnosed as having an HSP-S phenotype.

Complicated HSP was most frequently associated with intellectual disability. The associated clinical symptoms and signs are listed in Figure 2. Of the 23 patients, $20(87 \%)$ had intellectual disability, two $(8.6 \%)$ had a normal intelligence until the time of data collection, but one patient could not be assessed due to his age. Six patients (26\%) reported epileptic seizures at some time in their life (febrile seizure in one, isolated seizure in one and recurrent in four). The clinical and epidemiological data are listed in Table 2.

\section{HSP-S versus HSP-C}

There were no statistical differences between the simple and complicated groups in relation to skin color, sex, presence or absence of familial cases, and age at first appointment. 
Table 1. HSP-S - Clinical and epidemiological data.

\begin{tabular}{|c|c|c|c|c|c|c|c|c|c|c|}
\hline Variable & $\begin{array}{c}\text { Age at onset } \\
\text { of symptoms } \\
\text { (years) }\end{array}$ & $\begin{array}{l}\text { Age at first } \\
\text { appointment } \\
\text { (years) }\end{array}$ & $\begin{array}{c}\text { Time to } \\
\text { diagnosis } \\
\text { after disease } \\
\text { onset (years) }\end{array}$ & Sex & $\begin{array}{l}\text { Skin } \\
\text { color }\end{array}$ & Consanguinity & $\begin{array}{l}\text { Family } \\
\text { history }\end{array}$ & $\begin{array}{l}\text { Inheritance } \\
\text { pattern }\end{array}$ & Progression & Gait \\
\hline 1 & 5 & 10 & 4.6 & M & W & - & - & $\begin{array}{l}\text { Sporadic? } \\
\text { X-linked? }\end{array}$ & + & 1 \\
\hline 2 & 4 & 5 & 1.9 & F & $\mathrm{BR}$ & - & $\begin{array}{l}\text { Mother and } \\
\text { male cousin }\end{array}$ & $\begin{array}{c}\text { Autosomal } \\
\text { dominant }\end{array}$ & + & I \\
\hline 3 & 1 & 2 & 2 & M & $\mathrm{BL}$ & + & - & $\begin{array}{c}\text { Autosomal } \\
\text { recessive }\end{array}$ & + & I \\
\hline 4 & 1 & 4 & 4.1 & M & W & - & - & $\begin{array}{l}\text { Sporadic? } \\
\text { X-linked? }\end{array}$ & - & 1 \\
\hline 5 & 6 & 6 & 0.6 & M & $\mathrm{BR}$ & - & - & $\begin{array}{l}\text { Sporadic? } \\
\text { X-linked? }\end{array}$ & + & I \\
\hline 6 & 1 & 5 & 6.7 & M & Y & - & - & $\begin{array}{l}\text { Sporadic? } \\
\text { X-linked? }\end{array}$ & - & I \\
\hline 7 & 10 & 5 & 0 & $F$ & W & - & Mother & $\begin{array}{c}\text { Autosomal } \\
\text { dominant }\end{array}$ & + & I \\
\hline 8 & 4 & 11 & 8.1 & $\mathrm{~F}$ & W & + & Father & $\begin{array}{c}\text { Autosomal } \\
\text { dominant }\end{array}$ & + & WS \\
\hline 9 & 1 & 1.5 & 0.6 & M & $\mathrm{BR}$ & - & Grandfather & $\begin{array}{c}\text { Autosomal } \\
\text { dominant }\end{array}$ & - & I \\
\hline 10 & 2 & 4 & 2 & $\mathrm{~F}$ & $\mathrm{BL}$ & - & - & Sporadic? & + & I \\
\hline 11 & 0.8 & 2 & 1.8 & $\mathrm{~F}$ & W & - & - & Sporadic? & - & I \\
\hline 12 & 1 & 3 & 3 & M & $\mathrm{BR}$ & - & - & $\begin{array}{l}\text { Sporadic? } \\
\text { X-linked? }\end{array}$ & - & 1 \\
\hline
\end{tabular}

M: male; F: female;W: white; BR: brown; BL: black;Y:yellow;I: independent; WS: require walking support.

C-HSP: clinical associations

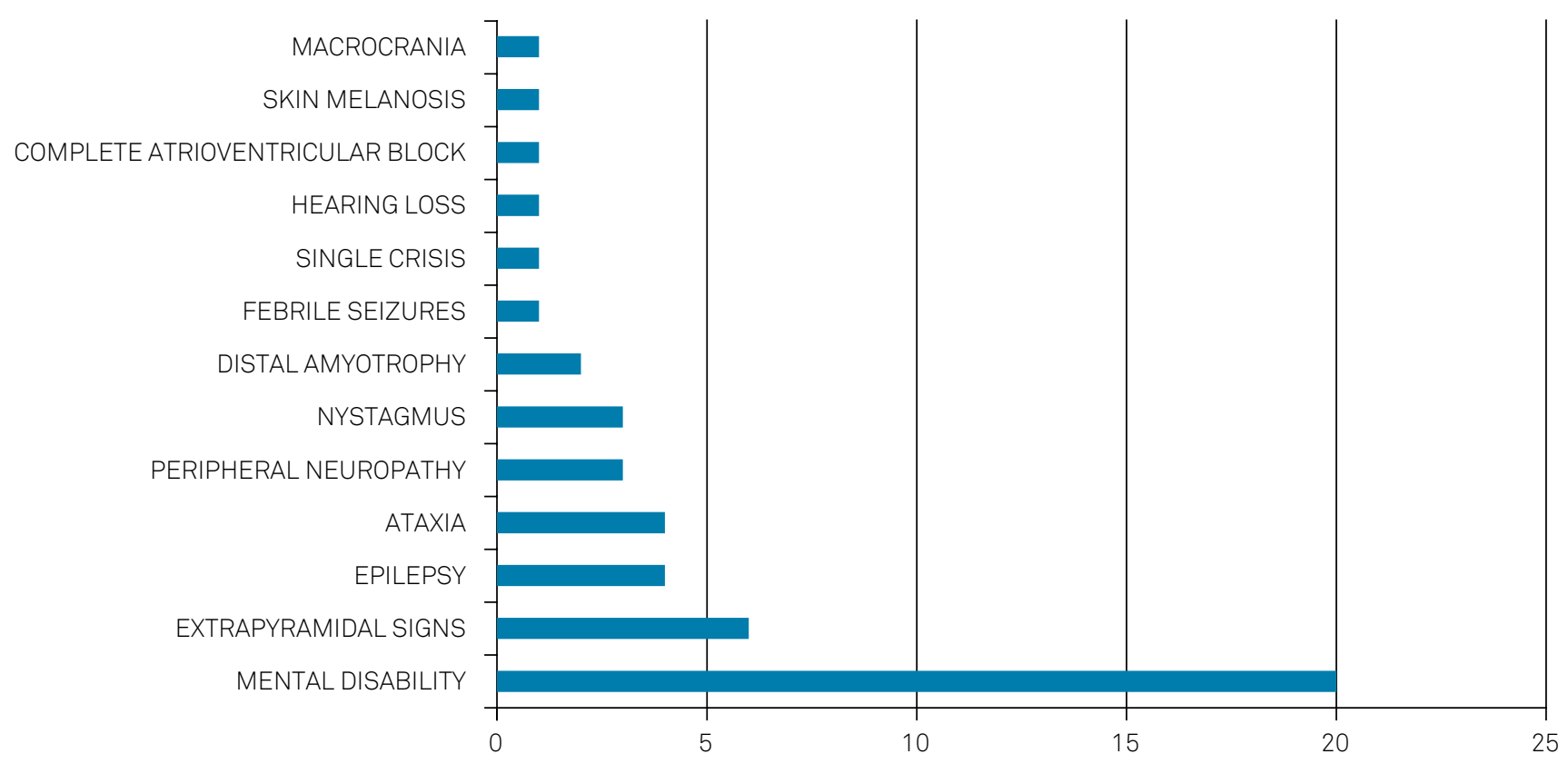

Figure 2. Neurological and systemic findings in HSP-C patients. Note: some patients had more than one clinical condition.

However, there was a statistically significant difference $(p<0.05)$ regarding the age of onset of symptoms and the time elapsed between the onset of symptoms and final diagnosis between the two groups. In the HSP-C group, the disease manifested earlier and the diagnosis was later (the statistical tests and variables are listed in Table 3).

\section{Neuroimaging findings}

All patients underwent brain MRI. Scans were normal in all patients with HSP-S. In patients with HSP-C, scans were normal in $10(43.4 \%)$ patients, whereas in six $(26.1 \%)$ patients nonspecific changes were present in white matter; in four (17.4\%) there was a thin corpus callosum, 


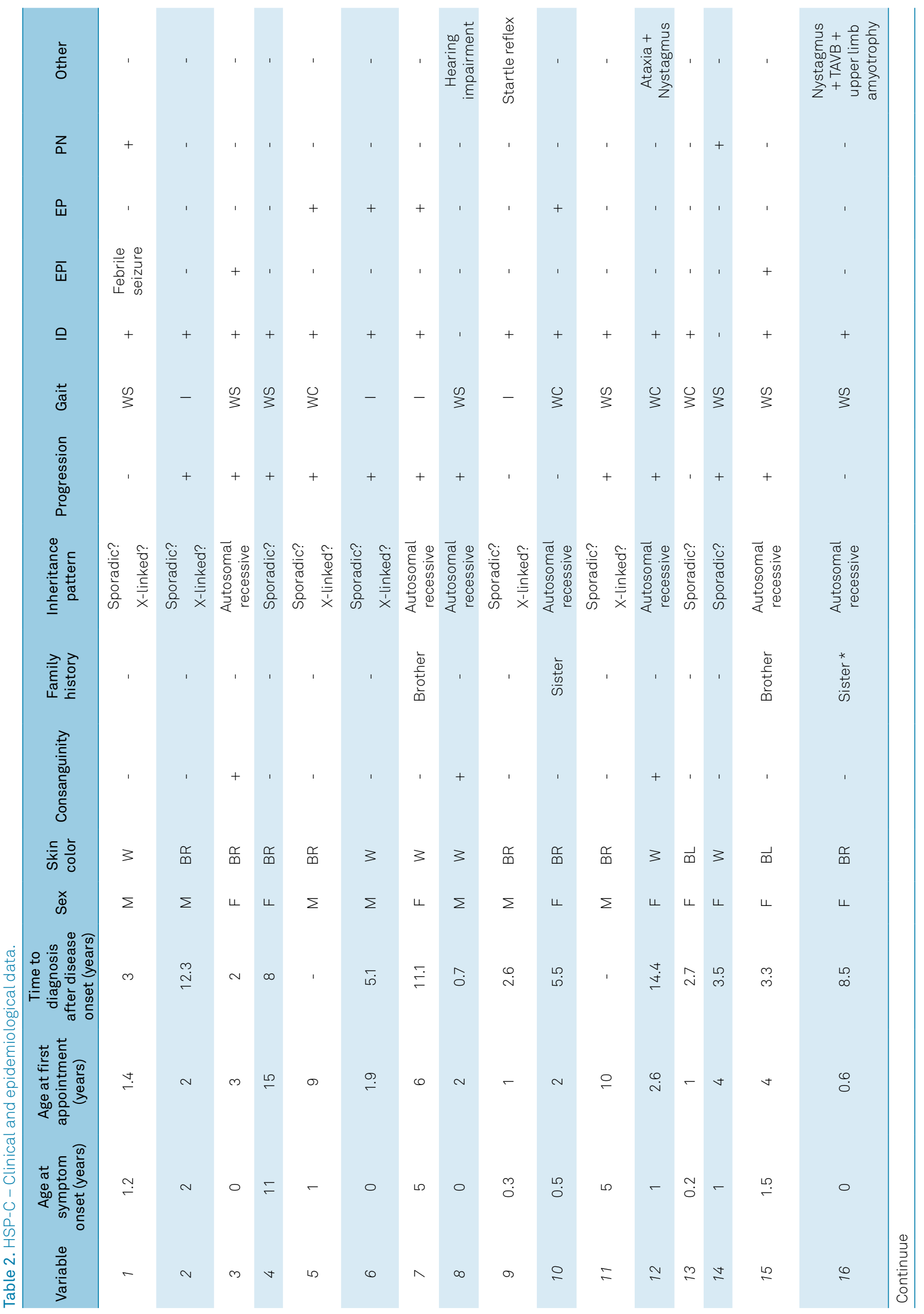




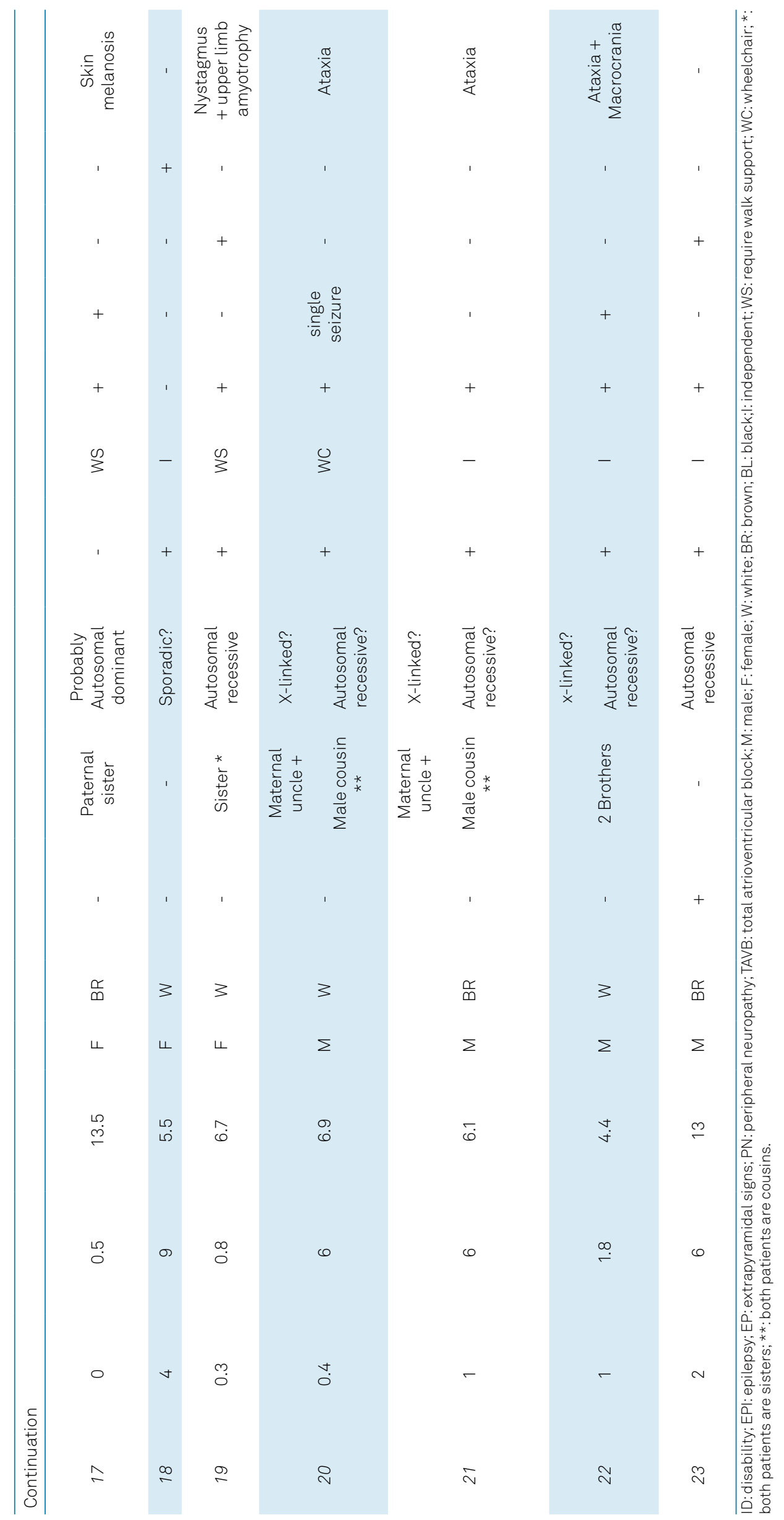

Ortega RPM. Pediatric hereditary spastic paraplegia

15 
Table 3. Statistical analysis of the variables in HSP-S and HSP-C groups.

\begin{tabular}{|c|c|c|c|c|c|c|c|}
\hline Variable & Group & Mean & Median & SD & Minimum & Maximum & $\mathrm{p}$-value \\
\hline \multirow{3}{*}{ Age at onset of symptoms } & Overall & 2.0 & 1.0 & 2.8 & 0.0 & 11.0 & \multirow{3}{*}{$0.023 *$} \\
\hline & Simple & 2.9 & 1.5 & 3.0 & 0.8 & 10.8 & \\
\hline & Complicated & 1.6 & 1.0 & 2.5 & 0.0 & 11.0 & \\
\hline \multirow{3}{*}{ Age at first appointment } & Overall & 4.6 & 3.8 & 3.7 & 0.5 & 15.2 & \multirow{3}{*}{$0.187 *$} \\
\hline & Simple & 5.1 & 4.9 & 2.7 & 1.5 & 11.9 & \\
\hline & Complicated & 4.3 & 2.2 & 4.2 & 0.5 & 15.2 & \\
\hline \multirow{3}{*}{$\begin{array}{l}\text { Time between onset of } \\
\text { symptoms and HSP diagnosis }\end{array}$} & Overall & 5.2 & 4.4 & 3.9 & 0.0 & 14.4 & \multirow{3}{*}{$0.013^{* *}$} \\
\hline & Simple & 3.0 & 2.0 & 2.5 & 0.0 & 8.2 & \\
\hline & Complicated & 6.4 & 5.5 & 4.1 & 0.8 & 14.4 & \\
\hline
\end{tabular}

*Mann-Whitney Test; **Student's t test.
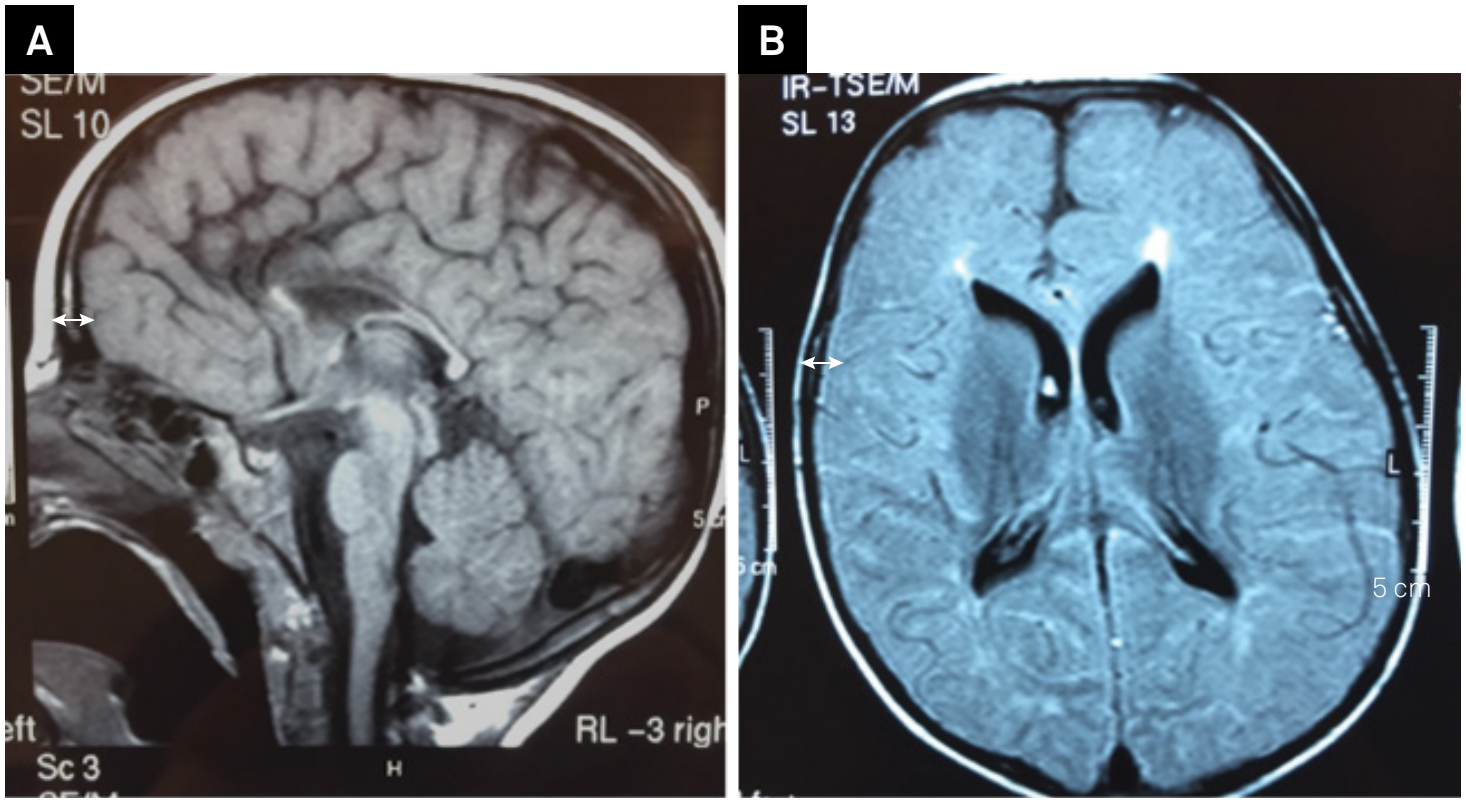

Figure 3. Magnetic resonance imaging of the brain in a patient with HSP-C: Sagittal T1-weighted imaging showing thinning of the corpus callosum (A). Axial FLAIR imaging showing the "ears of the lynx" sign (B).

in three of whom the "ears of the lynx" sign was observed (Figure 3); in two (8.7\%) cerebellar atrophy; and in one (4.3\%) nonspecific signal changes in the basal ganglia were identified.

Spinal cord MRI was performed in 21 patients (12 in the HSP-S group and nine in the HSP-C group). Hemangioma without spinal cord compression $(n=1)$, spina bifida without spinal cord involvement $(n=1)$, and hyperintensity of the lumbar roots following contrast injection $(\mathrm{n}=1)$ were individually encountered in three patients of the HSP-C group.

\section{Electroneuromyography findings}

Eight patients of the HSP-S group were tested, with normal results. From 13 patients of the HSP-C group who were tested, a symmetric, length-dependent, and dying-back pattern characteristic of axonal peripheral polyneuropathy was noted in three individuals (two with purely motor, and one with motor and sensory impairment).

\section{Fundoscopic findings}

All patients but one in the HSP-S group had a fundoscopic examination. The results were normal. This examination was performed in 20 patients of the HSP-C group. Pale papillae were present in two and optic atrophy was found in one.

\section{Audiology findings}

Twenty patients underwent auditory assessment with audiometry or evoked potentials (eight from the HSP-S group and 12 from the HSP-C group). Sensorineural hearing loss was detected in one patient in the HSP-C group.

\section{DISCUSSION}

The diagnosis of HSP in children poses several problems. Often, the progression of the symptoms is very slow, mimicking the diplegic form of cerebral palsy. Absence of a positive family history due to de novo mutations or lack of recognition 
of the disease in relatives is a common event. Other neurological diseases (inflammatory, metabolic, degenerative) may be clinically similar. Therefore, in children with a suspected clinical diagnosis of HSP, a complete battery of tests must be performed to achieve the correct diagnosis.

Our sample of 35 children, selected after careful clinical and laboratory studies, may be considered as having HSP with a very high degree of probability even in the absence of genetic tests (which are not always conclusive).

There are only a few studies devoted to pediatric HSP (Table 4). Two of them analyzed only the simple form of $\mathrm{HSP}^{7,16}$, and the other two studied both HSP-S and HSP-C ${ }^{17,18}$.

The correlation among their and our findings is shown in Table 4. In the two series by Koul et al. ${ }^{17}$ and Kumar et al. ${ }^{18}$, the frequency of HSP-C is somewhat higher. The high frequency of familial cases in the series by Koul et al. may be due to the high rate of parent consanguinity in their cohort.

In our series, the onset of the disease occurred earlier in the HSP-C patients. This finding could be due to the fact that associated neurological abnormalities in HSP-C may have facilitated earlier identification of the disease.

The mean time elapsed between the disease onset and the final diagnosis was longer in HSP-C patients (three years in HSP-S and 6.4 years in HSP-C). This delay was probably due to the complexity of the associated symptoms and the multiple differential diagnostic tests.

Motor impairment was less severe in the HSP-S group, all patients being ambulatory with or without support, whereas most of the HSP-C patients were wheelchair-dependent.

Intellectual disability was the most frequent event associated with HSP in the complicated form. In our series, this association was present in $87 \%$ of the patients. In the series by Koul et al. ${ }^{17}$, this number was lower (40\%). This discrepancy may be explained by the lack of standardized criteria for intellectual disability assessment, and by the fact that, in this series, $60 \%$ of the children were below the age of one year.

Thinning of the corpus callosum, when present, occurs in autosomal recessive HSP-C, and mutation of the SPG11 gene is frequently encountered ${ }^{19,20}$. In our series, this malformation was found in four patients, three of whom showed the "ears of the lynx" sign, which was recently described ${ }^{21}$. Autosomal recessive inheritance may be considered in two of these patients because parental consanguinity was detected in one and another had an affected sibling.

Although previously described in a series including mainly adult patients ${ }^{22}$, reduction of the volume of the spinal cord was not present in any of our patients, or in the pediatric patients studied by Koul et al. ${ }^{17}$. However, it should be stated that although the radiology evaluation was carried out by an experienced neuroradiologist, volumetric analysis according to the criteria described by Hedera et al. ${ }^{22}$ was not performed. Furthermore, spinal cord atrophy could be a late event in the clinical course of the disease.

Peripheral neuropathy was present in three HSP-C patients, one of whom had associated intellectual disability, thin corpus callosum, and nonspecific changes in the white matter. Peripheral neuropathy has been previously described in patients with HSP-C ${ }^{23}$. It is known that there are mutations in genes such as ATL1 (SPG3A) and BSCL2 (SPG17) responsible for either HSP or Charcot Marie Tooth disease ${ }^{24}$.

One patient of this series, classified as HSP-C, has a sister with HSP-S. This may be evidence that the same genetic mutation may be responsible for different phenotypes ${ }^{25}$. Indeed, this phenomenon has been highlighted as more and more genetic mutations are being discovered.

The concept that there is a continuum between HSP and other neurodegenerative diseases has been previously postulated ${ }^{26}$.

No pathogenic genetic anomaly was identified in the exome sequencing performed in one patient with HSP-S phenotype. This finding is not surprising as inconclusive results on genetic analysis, carried out with different techniques such as exome sequencing, genome sequencing or assessment of specific mutation depending on the patient phenotype, occur in one-third to half of the patients ${ }^{17,27}$. In one series comprising HSP-S sporadic patients, positive molecular diagnosis was achieved in only $28 \%{ }^{28}$.

Thus, the necessity of a rigorous evaluation of the patients in order to reach a secure diagnosis on clinical grounds is obvious. This is particularly necessary in pediatric patients where the clinical diagnosis is much more difficult than in adults. Working in the way we have done in this study, it was possible to select patients for further genetic evaluation, and genetic counseling, which must proceed, even in the absence of positive genetic results.

Table 4. Pediatric HSP. Review of the literature.

\begin{tabular}{|c|c|c|c|c|c|c|c|}
\hline Year & Author & Country & $\mathrm{N}$ & Simple/Complicated & Sex & Family Recurrence & Consanguinity \\
\hline 2011 & Battini et al. ${ }^{16}$ & Italy & 14 & $100 \%$ HSP-S & - & $7 \%$ & - \\
\hline 2013 & Koul et al..$^{17}$ & Oman & 74 & $81 \%$ HSP-C & $56.8 \% \mathrm{M}$ & $98 \%$ & $91 \%$ \\
\hline 2016 & Polymeris et al.? & Greece & 15 & $100 \%$ HSP-S & $80 \% \mathrm{M}$ & $33.3 \%$ & $0 \%$ \\
\hline 2016 & Kumar et al..$^{18}$ & India & 9 & $77 \% \mathrm{HSP}-\mathrm{C}$ & - & $22.2 \%$ & $66.6 \%$ \\
\hline 2017 & Our series & Brazil & 35 & $65.8 \% \mathrm{HSP}-\mathrm{C}$ & $51.4 \% \mathrm{M}$ & $37.1 \%$ & $17.1 \%$ \\
\hline
\end{tabular}


1. Appleton RE, Farrell K, Dunn HG. 'Pure' and 'complicated' forms of hereditary spastic paraplegia presenting in childhood. Dev Med Child Neurol. 1991 Apr;33(4):304-12. https://doi.org/10.1111/j.1469-8749.1991.tb14881.x

2. Ruano L, Melo C, Silva MC, Coutinho P. The global epidemiology of hereditary ataxia and spastic paraplegia: a systematic review of prevalence studies. Neuroepidemiology. 2014;42(3):174-83. https://doi.org/10.1159/000358801

3. Fink JK. Hereditary spastic paraplegia overview. GeneReviews ${ }^{\circledR}$. Seattle: University of Washington; 2000.

4. Sedel F, Fontaine B, Saudubray JM, Lyon-Caen O. Hereditary spastic paraparesis in adults associated with inborn errors of metabolism: a diagnostic approach.J Inherit Metab Dis. 2007 Nov;30(6):855-64. https://doi.org/10.1007/s10545-007-0745-1

5. García-Cazorla A, Wolf NI, Serrano M, Pérez-Dueñas B, Pineda $\mathrm{M}$, Campistol $\mathrm{J}$ et al. Inborn errors of metabolism and motor disturbances in children. J Inherit Metab Dis. 2009 Oct;32(5):618-29. https://doi.org/10.1007/s10545-009-1194-9

6. Hensiek A, Kirker S, Reid E. Diagnosis, investigation and management of hereditary spastic paraplegias in the era of next-generation sequencing. J Neurol. $2015 \mathrm{Jul} ; 262(7): 1601-12$. https://doi.org/10.1007/s00415-014-7598-y

7. Polymeris AA, Tessa A, Anagnostopoulou K, Rubegni A, Galatolo D, Dinopoulos A et al. A series of Greek children with pure hereditary spastic paraplegia: clinical features and genetic findings. J Neurol. 2016 Aug;263(8):1604-11. https://doi.org/10.1007/s00415-016-8179-z

8. Schüle R, Schöls L. Genetics of hereditary spastic paraplegias. Semin Neurol. 2011 Nov;31(5):484-93. https://doi.org/10.1055/s-0031-1299787

9. Lo Giudice T, Lombardi F, Santorelli FM, Kawarai T, Orlacchio A. Hereditary spastic paraplegia: clinical-genetic characteristics and evolving molecular mechanisms. Exp Neurol. 2014 Nov;261:518-39. https://doi.org/10.1016/j.expneurol.2014.06.011

10. Schüle R, Schöls L. [Ataxias and hereditary spastic paraplegias]. Nervenarzt. $2017 \mathrm{Jul} ; 88(7): 720-7$. German. https://doi.org/10.1007/s00115-017-0357-4

11. Faber I, Servelhere KR, Martinez AR, D'Abreu A, Lopes-Cendes I, França Junior MC. Clinical features and management of hereditary spastic paraplegia. Arq Neuropsiquiatr. 2014 Mar;72(3):219-26. https://doi.org/10.1590/0004-282X20130248

12. de Bot ST, van de Warrenburg BP, Kremer HP, Willemsen MA. Child neurology: hereditary spastic paraplegia in children. Neurology. 2010 Nov;75(19):e75-9. https://doi.org/10.1212/WNL.0b013e3181fc2776

13. Ashwal S, Russman BS, Blasco PA, Miller G, Sandler A, Shevell M et al. Practice parameter: diagnostic assessment of the child with cerebral palsy: report of the Quality Standards Subcommittee of the American Academy of Neurology and the Practice Committee of the Child Neurology Society. Neurology. 2004 Mar;62(6):851-63. https://doi.org/10.1212/01.WNL.0000117981.35364.1B

14. Faber I, Pereira ER, Martinez AR, França M Jr, Teive HA. Hereditary spastic paraplegia from 1880 to 2017: an historical review. Arq Neuropsiquiatr. 2017 Nov;75(11):813-8. https://doi.org/10.1590/0004-282×20170160

15. American Psychiatric Association. Manual diagnóstico e estatístico de transtornos mentais DSM-5. Porto Alegre:Artmed, 2014.
16. Battini R, Fogli A, Borghetti D, Michelucci A, Perazza S, Baldinotti F et al. Clinical and genetic findings in a series of Italian children with pure hereditary spastic paraplegia. Eur J Neurol. 2011 Jan;18(1):150-7. https://doi.org/10.1111/j.1468-1331.2010.03102.x

17. Koul R, Al-Murshedi FM, Al-Azri FM, Mani R, Abdelrahim RA, Koul V et al. Clinical spectrum of hereditary spastic paraplegia in children: a study of 74 cases. Sultan Qaboos Univ Med J. 2013 Aug;13(3):371-9. https://doi.org/10.12816/0003258

18. Kumar KR, Wali GM, Kamate M, Wali G, Minoche AE, Puttick C et al. Defining the genetic basis of early onset hereditary spastic paraplegia using whole genome sequencing. Neurogenetics. 2016 Oct;17(4):265-70. https://doi.org/10.1007/s10048-016-0495-z

19. Stevanin G, Azzedine H, Denora P, Boukhris A, Tazir M, Lossos A et al. Mutations in SPG11 are frequent in autosomal recessive spastic paraplegia with thin corpus callosum, cognitive decline and lower motor neuron degeneration. Brain. 2008 Mar;131(Pt 3):772-84. https://doi.org/10.1093/brain/awm293

20. França MC Jr, Yasuda CL, Pereira FR, D’Abreu A, Lopes-Ramos CM, Rosa MV et al. White and grey matter abnormalities in patients with SPG11 mutations.J Neurol Neurosurg Psychiatry. 2012 Aug;83(8):828-33. https://doi.org/10.1136/jnnp-2011-300129

21. Riverol M, Samaranch L, Pascual B, Pastor P, Irigoyen J, Pastor MA, et al. Forceps minor region signal abnormality "ears of the lynx": an early MRI finding in spastic paraparesis with thin corpus callosum and mutations in the spatacsin gene (SPG11) on chromosome 15. J Neuroimaging. 2009 Jan;19(1):52-60. https://doi.org/10.1111/j.1552-6569.2008.00327.x

22. Hedera P, Eldevik OP, Maly P, Rainier S, Fink JK. Spinal cord magnetic resonance imaging in autosomal dominant hereditary spastic paraplegia. Neuroradiology. 2005 Oct;47(10):730-4. https://doi.org/10.1007/s00234-005-1415-3

23. Pensato V, Castellotti B, Gellera C, Pareyson D, Ciano C, Nanetti L et al. Overlapping phenotypes in complex spastic paraplegias SPG11, SPG15, SPG35 and SPG48. Brain. 2014 Jul;137(Pt 7):1907-20. https://doi.org/10.1093/brain/awu121

24. Timmerman V, Clowes VE, Reid E. Overlapping molecular pathological themes link Charcot-Marie-Tooth neuropathies and hereditary spastic paraplegias. Exp Neurol. 2013 Aug;246:14-25. https://doi.org/10.1016/j.expneurol.2012.01.010

25. Chrestian N, Dupré N, Gan-Or Z, Szuto A, Chen S, Venkitachalam A et al. Clinical and genetic study of hereditary spastic paraplegia in Canada. Neurol Genet. 2016 Dec;3(1):e122. https://doi.org/10.1212/NXG.0000000000000122

26. Tesson C, Koht J, Stevanin G. Delving into the complexity of hereditary spastic paraplegias: how unexpected phenotypes and inheritance modes are revolutionizing their nosology. Hum Genet. 2015 Jun;134(6):511-38. https://doi.org/10.1007/s00439-015-1536-7

27. Kara E, Tucci A, Manzoni C, Lynch DS, Elpidorou M, Bettencourt $C$ et al. Genetic and phenotypic characterization of complex hereditary spastic paraplegia. Brain. 2016 Jul;139(Pt 7):1904-18. https://doi.org/10.1093/brain/aww111

28. Schüle R, Wiethoff S, Martus P, Karle KN, Otto S, Klebe S et al. Hereditary spastic paraplegia: clinicogenetic lessons from 608 patients. Ann Neurol. 2016 Apr;79(4):646-58. https://doi.org/10.1002/ana.24611 